\title{
Gambaran Faktor Risiko Kegawatdaruratan Obstetri pada Ibu Bersalin yang Masuk di Bagian Obstetri dan Ginekologi RSUD Dr. Rasidin Padang Tahun 2014
}

\author{
Diflayzer $^{1}$, Syahredi S.A ${ }^{2}$, Eka Nofita ${ }^{3}$
}

\begin{abstract}
Abstrak
Angka kematian ibu (AKI) di Indonesia masih tinggi diatas target MDGs. Fokus percepatan untuk menurunkan AKI adalah dengan deteksi kehamilan risiko tinggi menggunakan sistem pendekatan risiko dan penanganan yang adekuat melalui sistem rujukan terencana. Tujuan penelitian ini adalah mengetahui gambaran faktor risiko dan pelaksanaan rujukan di salah satu rumah sakit rujukan di Padang. Penelitian dilakukan pada seluruh ibu bersalin di RSUD DR. Rasidin Padang. Penelitian ini merupakan penelitian deskriptif dengan menggunakan data rekam medik periode Januari sampai Desember 2014. Hasil penelitian didapatkan frekuensi kasus kejadian terbanyak pada kelompok faktor risiko APGO adalah ibu hamil usia $\geq 35$ tahun (28,9\%), pada kelompok AGO adalah serotinus (52\%), pada kelompok AGDO adalah preeklampsia berat/eklampsia (96,6\%), kelompok skor terbanyak adalah kehamilan risiko sangat tinggi (KRST) $(46,6 \%)$ dan kriteria rujukan terbanyak adalah rujukan terlambat $(56,1 \%)$. Simpulan penelitian ini adalah bahwa ibu bersalin di RSUD DR. Rasidin Padang banyak yang termasuk kehamilan risiko sangat tinggi, namun kasus rujukan terlambat masih tinggi.
\end{abstract}

Kata kunci: sistem pendekatan risiko, rujukan terencana

\begin{abstract}
The maternal mortality rate (MMR) in Indonesia is still well above the MDG target. Focus acceleration for reducing the MMR is the detection of high-risk pregnancies using a system approach to risk and adequate treatment through referral systems planned. The objective of this study was to describe the risk factors and the implementation of referrals in one of the main referral hospital in Padang. The study was conducted on all women giving birth in DR. Rasidin Hospital Padang. This research was a descriptive study used medical records in DR. Rasidin Hospital Padang for the period January to December 2014. Result showed the highest frequency of occurrence of cases in the group of risk factors $A P G O$ is pregnant women $\geq 35$ years of age (28.9\%), in AGO group was postterm pregnancy (52\%), in AGDO group was preeclampsia/eclampsia (96.6\%), the major score of the group was very high-risk pregnancies (KRST) (46.6\%) and highest referral criteria was late referral (56.1\%). The conclusions of this research is the most of womens giving birth in DR. Rasidin Hospital Padang are included very high-risk pregnancies but late referral cases is still high.
\end{abstract}

Keywords: system approach to risk, referral planned

Affiliasi penulis: 1. Prodi Profesi Dokter FK Unand (Fakultas Kedokteran Universitas Andalas Padang), 2. Bagian Obstetri dan Ginekologi FK Unand/RSUP M. Jamil Padang, 3. Bagian Parasitologi FK Unand.

Korespondensi: Diflayzer. Email: adifflys@gmail.com, Telp: 087893092156

\section{PENDAHULUAN}

Kematian saat melahirkan menjadi faktor utama mortalitas perempuan pada puncak produktivitasnya. ${ }^{1}$ AKI tahun 2012 ini semakin menjauhi target Millenium Development Goals 2015. Berdasarkan hasil survei 
Fakultas Kedokteran Universitas Andalas tahun 2008, AKI di Sumatra Barat adalah 212 per 100.000 kelahiran hidup. $^{2}$

Data profil kesehatan Provinsi Sumatra Barat tahun 2012, mengungkapkan pencapaian penanganan komplikasi ibu hamil, bersalin, dan nifas di Provinsi Sumatra Barat tahun 2012 berada di bawah target. ${ }^{2}$ Persentase persalinan ditolong tenaga kesehatan di Provinsi Sumatra Barat tahun 2013 belum mencapai target rencana strategis (renstra) Kementerian Kesehatan tahun 2013. Terkait jadwal kunjungan Antenatal Care (ANC) yang merupakan salah satu pendukung utama dalam strategi pendekatan risiko, untuk Kunjungan 1 (K1) Provinsi Sumatra Barat telah memenuhi target. Namun, untuk Kunjungan 4 (K4) belum memenuhi target. ${ }^{3}$

Fokus percepatan penurunan AKI adalah deteksi, penanganan, dan rujukan kehamilan atau persalinan risiko tinggi. Salah satu model pelayanan untuk mengurangi AKI adalah dengan strategi pendekatan risiko (SPR), SPR ini hanya berhasil jika didukung oleh pelayanan berupa sistem rujukan (SR) yang baik. Rujukan harus berupa kegiatan yang terencana, bukan sebagai reaksi sesaat terhadap suatu keadaan yang tidak diinginkan). ${ }^{1}$ lbu hamil dengan masalah risiko tinggi membutuhkan pelayanan berkelanjutan yang adekuat dan spesialistik di pusat rujukan rumah sakit kabupaten/kota. ${ }^{4}$

Faktor risiko adalah sesuatu yang ada pada diri seseorang atau komunitas yang pada suatu waktu dapat menyebabkan ketidaknyamanan, kesakitan, bahkan kematian. ${ }^{1}$ Kehamilan dengan faktor risiko tinggi adalah suatu kehamilan yang membawa ancaman bagi jiwa dan kesehatan ibu dan bayi. ${ }^{5}$ Kehamilan risiko tinggi memerlukan pengawasan yang lebih intensif dan proaktif dengan tujuan memperkecil kesulitan dan komplikasi yang terjadi, sehingga hasil akhirnya mendekati well born baby dan well health mother. ${ }^{6}$

Berdasarkan pengelompokkan tersebut, rujukan terencana mempunyai 2 model, yaitu rujukan dini berencana dan rujukan tepat waktu. Rujukan dini berencana dilakukan pada ibu hamil dengan Ada Potensi Gawat Obstetri (APGO) dan Ada Gawat Obstetri (AGO) yang diperkirakan mungkin masih mengalami komplikasi dalam persalinan, sedangkan rujukan tepat waktu dilakukan upaya penyelamatan nyawa ibu dan bayinya pada ibu dengan Ada Gawat Obstetri (AGDO) dan ibu komplikasi obstetri dini dalam persalinan. $^{7}$

Penelitian yang dilakukan di RSUD Gambiran Kota Kediri Jawa Timur mendapatkan frekuensi kegawatdaruratan obstetri sebagian besar adalah faktor risiko APGO diikuti oleh AGO dan sebagian kecil AGDO. Penelitian tersebut mrndapatkan hampir seluruh responden yang memiliki faktor risiko kegawatdaruratan pada APGO, AGO, AGDO dirujuk secara terencana. ${ }^{8}$

Penelitian terkait salah satu faktor risiko dari 20 faktor risiko yaitu bekas seksio sesarea mendapatkan Ibu hamil dengan bekas seksio sesarea yang datang dengan rujukan dini berencana (melalui poli kebidanan RSUP dr. M. Jamil Padang) ke Bagian Obstetri RSUP dr. M. Jamil Padang yaitu sebesar 5,7\% dan rujukan yang paling banyak terjadi yaitu rujukan melalui IGD (Intalasi Gawat Darurat) RSUP dr. M. Jamil Padang sebanyak $57,7 \%$. ${ }^{9}$

Berdasarkan data diatas tampak bahwa AKI di Indonesia dan Sumatra Barat masih tergolong tinggi dan beberapa model pelayanan ibu hamil, bersalin, dan nifas di Sumatra Barat belum mencapai target. Oleh karena itu, perlu penelitian untuk mengetahui gambaran distribusi faktor risiko kegawatdaruratan obstetri dan pelaksanaan rujukan terencana di RSUD DR. Rasidin sebagai salah satu informasi keadaan di lapangan yang berguna untuk perencanaan penanggulangan permasalahan terkait pelayanan kesehatan ibu hamil, bersalin, dan nifas selanjutnya.

\section{METODE}

Penelitian telah dilakukan dari bulan Agustus 2015 sampai januari 2016 di Bagian Rekam Medis RSUD DR. Rasidin Padang. Populasi penelitian ini adalah semua ibu hamil yang melakukan persalinan di bagian obstetri dan ginekologi RSUD DR. Rasidin padang yang tercatat di rekam medik dari bulan Januari sampai Desember. Sampel pada penelitian ini adalah semua ibu bersalin di RSUD DR. Rasidin padang yang mempunyai rekam medik mulai Januari sampai Desember 2014 dan memiliki data yang 
lengkap sehubungan data yang diambil. Jenis penelitian ini adalah studi deskriptif. Penelitian dilakukan dengan melihat status rekam medis. Data dikumpulkan dari seluruh rekam medis ibu hamil yang melakukan persalinan di RSUD Dr. Rasidin periode 1 Januari 2014 sampai 31 Desember 2014. data yang diperoleh diolah secara manual kemudian ditabulasikan, dianalisa dan disajikan dengan tabel.

\section{HASIL}

Tabel 1. Distribusi frekuensi ibu bersalin dengan faktor risiko $A P G O$

\begin{tabular}{lcc}
\hline \multicolumn{1}{c}{ APGO } & $\mathbf{f}$ & $\%$ \\
Primi muda & 1 & 0,3 \\
Primi tua & 3 & 0,8 \\
Primi tua & 4 & 1,1 \\
sekunder & & \\
Anak terkecil $<2$ & 6 & 1,6 \\
tahun & & \\
Grande multi & 94 & 26,4 \\
Umur $\geq 35$ tahun & 103 & 28,9 \\
Tinggi badan $\leq$ & 13 & 3,6 \\
145 cm & & 15 \\
Riwayat obstetri & 54 & \\
jelek & & 2,8 \\
Riwayat partus & 10 & 10,1 \\
tindakan & & \\
Bekas SC & 68 & \\
$\quad$ Total & 356 & \\
\hline
\end{tabular}

Berdasarkan Tabel 1 didapatkan bahwa kasus faktor risiko tertinggi untuk APGO adalah ibu bersalin dengan umur 35 tahun atau lebih yaitu 103 kasus $(28,9 \%)$.

Tabel 2. Distribusi frekuensi ibu bersalin dengan faktor risiko AGO

\begin{tabular}{lcc}
\hline \multicolumn{1}{c}{ AGO } & $\mathbf{f}$ & $\%$ \\
\hline Penyakit ibu & 12 & 12 \\
Preeklampsia & 4 & 4 \\
ringan & & \\
Hamil kembar & 3 & 3 \\
Hidramnion & 1 & 1 \\
Serotinus & 52 & 52 \\
Intrauterine fetal & 7 & 7 \\
death & & \\
Letak sungsang & 17 & 17 \\
Letak lintang & 4 & 4 \\
\multicolumn{1}{c}{ Total } & 100 & 100 \\
\hline
\end{tabular}

Berdasarkan Tabel 2 kejadian faktor risiko untuk AGO yang terbanyak adalah serotinus yaitu 52 kasus (52\%)

Tabel 3. Distribusi frekuensi ibu bersalin dengan faktor risiko AGDO

\begin{tabular}{lcc}
\hline \multicolumn{1}{c}{ AGDO } & $\mathbf{f}$ & $\%$ \\
\hline $\begin{array}{l}\text { Perdarahan } \\
\text { antepartum } \\
\text { Preeklampsia } \\
\text { berat/eklampsia } \\
\quad \text { Total }\end{array}$ & 1 & 3,3 \\
\hline
\end{tabular}

Berdasarkan Tabel 3 kejadian faktor risiko terbanyak untuk AGDO adalah preeklampsia berat/eklampsia yaitu sebanyak 29 kasus.

Tabel 4. Distribusi frekuensi skor pada ibu bersalin

\begin{tabular}{lcc}
\hline \multicolumn{1}{c}{ Skor risiko } & $\mathbf{f}$ & $\%$ \\
\hline $\begin{array}{l}\text { Kehamilan risiko } \\
\text { rendah }\end{array}$ & 113 & 30,2 \\
$\begin{array}{l}\text { Kehamilan risiko } \\
\text { tinggi }\end{array}$ & 86 & 23 \\
$\begin{array}{l}\text { Kehamilan risiko } \\
\text { sangat tinggi }\end{array}$ & 174 & 46,6 \\
$\quad$ Total & 373 & 100 \\
\hline
\end{tabular}

Berdasarkan Tabel 4, kasus kehamilan risiko sangat tinggi (KRST) merupakan yang terbanyak yaitu 174 kasus $(46,6 \%)$.

Tabel 5. Distribusi frekuensi kriteria rujukan pada ibu bersalin yang memiliki faktor risiko.

\begin{tabular}{|l|c|c|}
\hline \multicolumn{1}{|c|}{$\begin{array}{c}\text { Kriteria } \\
\text { rujukan }\end{array}$} & f & \% \\
\hline $\begin{array}{l}\text { Rujukan dini } \\
\text { berencana }\end{array}$ & 93 & 35,7 \\
\hline $\begin{array}{l}\text { Rujukan tepat } \\
\text { waktu }\end{array}$ & 21 & 86,1 \\
\hline $\begin{array}{l}\text { Rujukan } \\
\text { telambat }\end{array}$ & 146 & 100 \\
\hline \multicolumn{1}{|c|}{ Total } & 260 & \\
\hline
\end{tabular}

Frekuensi rujukan terlambat lebih tinggi yaitu 146 kasus $(56,1 \%)$. 


\section{PEMBAHASAN}

Penelitian ini mendapatkan bahwa kasus faktor risiko tertinggi untuk APGO adalah ibu bersalin dengan umur 35 tahun atau lebih dan yang paling sedikit adalah kasus primi muda. Penelitian yang dilakukan di 3 kabupaten yaitu Nganjuk, Probolinggo, dan Tranggalek didapatkan sebanyak $22 \%$ memliliki faktor risiko dari seluruh sampel yang ada. Peneliti memisahkan secara khusus ibu hamil yang hanya memiliki 1 faktor risiko, yaitu sebanyak 16,1\% dimana kasus terbanyak adalah usia $\geq 35$ tahun yaitu $3,1 \%$ dan kasus yang paling sedikit adalah primi tua dengan $0,2 \%{ }^{10}$ Penelitian yang dilakukan di RSUD Gambiran Kota Kediri mendapatkan kasus faktor risiko umur $\geq 35$ tahun juga merupakan faktor risiko terbanyak yaitu 52 kasus $(29,2 \%)$ sedangkan angka terkecil yaitu masingmasing sebanyak 3 kasus didapat pada 3 faktor risiko yaitu primi muda, primi tua dan anak terkecil $<2$ tahun. ${ }^{8}$

Jumlah bayi yang dilahirkan oleh wanita pada usia 30-an akhir semakin meningkat selama dekade terakhir ini. Padahal wanita yang hamil pada usia $\geq 35$ tahun memiliki risiko untuk mendapatkan komplikasi lebih besar dari pada wanita yang lebih muda. Wanita yang hamil usia 35-40 tahun memiliki risiko tinggi untuk menderita diabetes gestasional, plasenta previa, lahir sungsang, pelahiran yang dibantu vakum atau forsep, operasi seksio sesar baik yang elektif ataupun emergensi, perdarahan postpartum, anak lahir di bawah usia 32 minggu, berat lahir rendah dan bayi mati saat lahir, sedangkan wanita usia lebih dari 40 tahun memiliki risiko yang lebih besar lagi untuk medapatkan komplikasi di atas. ${ }^{11}$

Alasan wanita untuk menunda kehamilan bervariasi diseluruh dunia. Wanita yang mengejar karir atau tujuan finansial, pemakaian kontrasepsi yang lebih baik, harapan hidup yang lebih panjang, dan pendidikan yang lebih tinggi merupakan alasan-alasan yang sering disebut sebagai penyabab banyaknya ibu hamil pada usia 35 tahun atau lebih. Wanita hamil usia $\geq 35$ tahun dianggap sudah lanjut usia dan juga mempunyai risiko tinggi untuk memiliki komplikasi baik saat kehamilan dan persalinan. ${ }^{12}$

Kasus AGO yang terbanyak pada penelitian ini adalah serotinus dan yang paling sedikit adalah kasus hidramnion. Pada penelitian lain mendapatkan bahwa kejadian faktor risiko tertinggi adalah letak sungsang dan yang paling sedikit dengan masing 1 kasus adalah hidramnion dan letak lintang. ${ }^{8}$ Penelitian lainnya mendapatkan kasus terbanyak faktor risiko AGO adalah penyakit ibu. ${ }^{10}$

Kehamilan serotinus didefinisikan sebagai kehamilan yang berlangsung lebih dari 42 minggu (294 hari) atau tanggal taksiran persalinan ditambah 14 hari. $^{13}$ Pada banyak kasus, penyebab dari kehamilan serotinus tidak diketahui. Beberapa faktor risiko kehamilan serotinus adalah riwayat kehamilan serotinus sebelumnya, wanita yang hamil untuk pertama kali, umur ibu yang lebih dari 30 tahun, dan obesitas, termasuk juga predisposisi genetik. Seorang wanita yang dilahirkan dengan serotinus akan meningkatkan risiko sebanyak $49 \%$ untuk menjadi ibu hamil dengan serotinus pula. ${ }^{14}$

Saat ini belum ada penelitian yang mendapatkan efek suatu gen spesifik tertentu pada ibu dengan kehamilan yang memanjang. ${ }^{15}$ Kemungkinan adalah akibat polimorfisme pada gen terkait jalur fisiologis $\mathrm{CRH}$ (corticotropin releasing hormone) pada kehamilan. $\mathrm{CRH}$ ini merupakan salah satu hormon yang mempengaruhi lamanya kehamilan. Hormon ini akan meningkat selama kehamilan dan mencapai puncak pada saat akan bersalin. Pada wanita dengan serotinus, kecepatan peningkatan hormon ini menjadi lebih lambat dari pada wanita normal. ${ }^{13}$

Penyebab tersering dari kehamilan memanjang atau serotinus adalah penanggalan yang tidak akurat. Penggunaan kriteria klinis yang standar untuk menentukan taksiran tanggal persalinan cenderung untuk menaksir terlalu tinggi usia kehamilan dan oleh sebab itu meningkatkan insiden kehamilan serotinus. ${ }^{13}$ Penanggalan secara klinis ini bisa menyebabkan salah diagnosis untuk kehamilan serotinus. Penanggalan tradisional menggunakan penanggalan menstrusasi terakhir atau HPHT (hari pertama haid terakhir) yang berasumsi ovulasi terjadi pada hari ke 14 dapat menyebabkan taksiran umur kehamilan menjadi terlalu tinggi. $^{14}$

Kejadian faktor risiko terbanyak untuk AGDO pada penelitian ini adalah preeklampsia berat/eklampsia. Hal ini sejalan dengan penelitian 
Laili et al (2007) yang mendapatkan preeklampsia berat/ eklampsia sebagai jumlah tertinggi untuk AGDO yaitu sebanyak 23 kasus $(76,6 \%){ }^{8}$ Penelitian di RSUP DR. Kariadi Semarang tahun 2013 mendapatkan juga proporsi kejadian preeklampsia berat/eklampsia yaitu 84 kasus $(8,0 \%)$ lebih tinggi dari perdarahan anterpartum yaitu 56 kasus $(5,6 \%) .^{16}$

Risiko preeklampsia meningkat pada wanita yang mempunyai faktor-faktor risiko seperti wanita dengan riwayat prekampsia sebelumnya, wanita dengan antibodi fosofolipid, penderita diabetes, gameli, wanita yang hamil untuk pertama kalinya, riwayat keluarga preeklampsia, peningkatan tekanan darah (diastolik $\geq 80 \mathrm{mmHg}$ ) pada kunjungan pertama ANC dan umur ibu $\geq 40$ tahun. Penelitian lain juga menyebutkan wanita dengan jarak kehamilan lebih dari 10 tahun atau primi tua sekunder, penyakit autoimun, penyakit ginjal dan hipertensi kronis juga meningkatkan risiko preeklampsia. ${ }^{17}$

Penelitian ini mendapatkan kehamilan risiko sangat tinggi (KRST) merupakan yang terbanyak. Hal ini berbeda dengan penelitian Rochjati et al (2007) di mana kehamilan risiko rendah (KRR) merupakan kasus terbanyak yaitu $78 \%$, kemudian kehamilan risiko tinggi (KRT) sebesar 20,2\% dan kehamilan risiko sangat tinggi (KRST) sebesar $1,8 \% .{ }^{10} \mathrm{Hal}$ ini mungkin karena perbedaan pengambilan sampel dimana penelitian ini hanya memakai sampel di RSUD DR. Rasidin yang merupakan rumah sakit rujukan, sedangkan penelitian diatas mengambil sampel secara keseluruhan, baik dari Puskesmas, RSUD ataupun RSUP.

Dalam sistem rujukan, Rumah Sakit Kabupaten atau Kotamadya merupakan pusat rujukan primer, dengan kemampuan pelayanan obstetri neonatal esensial/emergensi komprehensif (PONEK) untuk ibu hamil dengan kegawatan dan kegawatdaruratan obstetri yang berasal dari unit pelayanan perifer, yaitu Polindes dan Puskesmas. Termasuk ibu KRST harus diberi penyuluhan untuk melahirkan minimal di rumah sakit Rumah Sakit Kabupaten/Kotamadya. ${ }^{1}$ Oleh karena itu puskesmas hanya menyelenggarakan pengawasan dan perawatan ibu hamil, bersalin dan nifas yg fisiologis (tanpa komplikasi atau punya risiko tinggi). ${ }^{5}$
Rujukan terencana terbagi menjadi rujukan dini berencana dan rujukan tepat waktu. Dari tabel dapat dilihat bahwa rujukan dini berencana dan rujukan tepat waktu masing-masing adalah 93 (35,7\%) dan 21 (8\%) kasus, maka total kasus rujukan terencana adalah gabungan kedua kedua nilai diatas yaitu 114 kasus $(43,7 \%)$. Frekuensi rujukan terlambat lebih tinggi yaitu 146 kasus $(56,1 \%)$.

Penelitian di RSUP DR. Kariadi Semarang tahun 2013 mendapatkan dari 860 pasien, kelompok yang dirujuk secara tepat rujukan atau rujukan terencana adalah $680(79,1 \%)$ dan kelompok yang dirujuk terlambat adalah 180 (20,9\%). Penelitian tersebut menjelaskan penyebab terlambat rujukan bisa karena tenaga kesehatan yang bersangkutan terlambat dalam mengambil keputusan untuk merujuk penderita, penderita terlambat sampai ditempat rujukan atau penderita terlambat memperoleh pelayanan di tempat rujukan. ${ }^{16}$

Penyebab rujukan terlambat pada ibu hamil yang memiliki faktor risiko adalah karena ibu hamil tersebut datang kebidan dengan kondisi usia kehamilan tua dan mendekati persalinan. Berdasarkan hal tersebut, rujukan terlambat kemungkinan disebabkan karena kurangnya kesadaran pasien tentang tanda bahaya pada kehamilan dan pengambilan keputusan mendapatkan perawatan oleh tenaga kesehatan. ${ }^{8}$

Ada empat faktor terlambat yang mempengaruhi kematian maternal. Faktor tersebut adalah terlambat mendeteksi tanda bahaya, terlambat mengambil keputusan merujuk, terlambat sampai di tempat rujukan, dan terlambat mendapatkan pertolongan di tempat rujukan. ${ }^{18}$

Empat faktor terlambat ini harus di perbaiki untuk mengurangi kasus terlambat rujukan. Keterlambatan mendeteksi masalah diantisipasi dengan melakukan edukasi kepada ibu hamil dan keluarganya, sehingga dapat mengenali tanda bahaya. Keterlambatan dalam mengambil keputusan diantisipasi dengan mengubah cara mengambil keputusan. Keterlambatan sampai di tempat tujuan diantisipasi dengan memperbaiki sistem transportasi, sehingga akses ke pusat pelayanan kesehatan dapat lebih mudah dan cepat. ${ }^{19}$ Keterlambatan penanganan 
di rumah sakit rujukan diantisipasi dengan meningkatkan kualitas pelayanan kesehatan melalui pelatihan dan meningkatkan prosedur dalam menghadapi situasi emergensi. ${ }^{18}$

Bidan sangat berperan dalam proses pengambilan keputusan. Pengetahuan dan sikap bidan tentang kasus rujukan berpengaruh positif terhadap ketepatan rujukan obstetri. ${ }^{20}$ Para kader kesehatan, seperti ibu-ibu PKK, kader posyandu, harus secara aktif mengenali dan mencari ibu hamil dengan faktor risiko kemudian memberikan komunikasi, informasi dan edukasi, sehingga keluarga dapat mengenali kemungkinan bahaya yang terjadi ${ }^{6}$ Ambulan merupakan transportasi utama yang harus dipersiapkan untuk merujuk dan setiap bidan, dokter terutama dokter spesialis kebidanan dan tenaga kesehatan lain di rumah sakit rujukan harus selalu siap siaga untuk menghadapi kasus emergensi obstetri.

\section{SIMPULAN}

Kasus faktor risiko tertinggi untuk ada potensi gawat obstetri (APGO) adalah ibu bersalin dengan umur 35 tahun atau lebih.

Kasus faktor risiko untuk ada gawat obstetri (AGO) yang terbanyak adalah serotinus.

Kejadian faktor risiko terbanyak untuk ada gawat darurat obstetri (AGDO) adalah preeklampsia berat/eklampsia.

Kasus kehamilan risiko sangat tinggi (KRST) merupakan kasus yang terbanyak pada ibu bersalin.

Frekuensi rujukan terlambat lebih tinggi dari pada rujukan terencana.

\section{UCAPAN TERIMAKASIH}

Terimakasih kepada semua pihak atas saran, masukan dan arahan dalam penelitian ini.

\section{DAFTAR PUSTAKA}

1. Martaadisoebrata D, Sastrawinata S, Saifuddin AB. Bunga rampai obstetri dan ginekologi sosial. Jakarta: PT Bina Sarwono Prawirohardjo; 2011.

2. Dinas Kesehatan Provinsi Sumatera Barat. Profil kesehatan Provinsi Sumatera Barat tahun 2012. 2012 (diunduh 15 Januari 2015). Tersedia dari: URL: HYPERLINK http://www.depkes.go.id/
resources/download/profil/PROFIL KES PROVIN

SI 2012/15 Profil Kes.Prov.JawaTimur 2012.pdf

3. Pusat Data Dan Informasi Kementerian Kesehatan RI. Ringkasan eksekutif data dan informasi kesehatan provinsi sumatera barat. 2013 (diunduh 1 September 2015) Tersedia dari: URL: HYPERLINK http://www.depkes.go.id/resources/ download/profil/PROFIL KES PROVINSI 2012/15 Profil Kes.Prov.JawaTimur 2012.pdf

4. Maryunani A, Puspita E. Program perencanaan persalinan dan pencegahan komplikasi (P4K). Jakarta: TIM; 2011.

5. Sofian A. Rustam Mochtar sinopsis obstetri obstetri obstetri operatif obstetri sosial. Edisi ke-3. Jakarta: EGC; 2012.

6. Manuaba IBG. Pengantar kuliah obstetrik dan ginekologi sosial. Jakarta: TIM; 2012.

7. Rocjati P. Rujukan terencana dalam sistim rujukan paripaurna terpadu kabupaten/kota. Surabaya: Airlangga University Press; 2004.

8. Laili F, Nugraha GI, Garna H. Hubungan faktor risiko kegawatdaruratan obstetrik menurut rochjati dengan pelaksanaan rujukan oleh bidan Di RSUD Gambiran Kediri. 2014 (diunduh 15 Januari 2015). Tersedia dari: URL: HYPERLINK http://pustaka.unpad.ac.id/wp-content/uploads/ 2014/10/Hubungan-Faktor-Risiko-Kegawat daruratan-Obstetri.pdf

9. Afriani A. Kasus persalinan dengan bekas seksio sesarea menurut keadaan waktu masuk di bagian Obstetrik dan Ginekologi RSUP Dr. M. Djamil Padang (skripsi). Padang: Fakultas Kedokteran Universitas Andalas; 2013.

10. Rochati P, Anondo D, Wijono SB, Santoso, Sugito. Pemantauan kematian ibu dan kematian bayi baru lahir melalui sistem rujukan terencana di Kabupaten Nganjuk, Probolinggo, dan TrenggalekJawa timur. 2007 (diunduh 29 Januari 2016). Tersedia dari: URL: HYPERLINK http://ejournal. litbang.depkes.go.id/index.php/bpk/article/downloa d/2145/1139

11. Jolly M, Sebire N, Harris J, Robinson S, Began I. The risks associated with pregnancy in women aged 35 years or older. 2000 (diunduh 29 Januari 2016). Tersedia dari: URL: HYPERLINK 
http://www.humrep.oxfordjournals.org/content/15/1 1/2433.short

12. Katwijk CV, Peeters LLH. Clinical aspects of pregnancy after the age of 35 years: a review of the literature. 1998 (diunduh 29 Januari 2016). Tersedia dari: URL: HYPERLINK http://humupd. oxfordjournals.org/content/4/2/185.short

13. Galal M, Symonds I, Murray H, Petraglia F, Smith R. Postterm pregnancy. 2012 (diunduh 29 Januari 2016). Tersedia dari: URL: HYPERLINK http:// www.ncbi.nlm.nih.gov/pmc/articles/PMC3991404/

14. Wang M. Common question about late-term and postterm pregnancy. 2014 (diunduh 1 Februari 2016). Tersedia dari: URL: HYPERLINK http://www.aafp.org/afp/2014/0801/p160.html

15. Schierding W, O'sullivan JM, Derraik JGB, Cutfield WS. Genes and post-term birth: late for delivery. 2014 (diunduh 6 maret 2016). Tersedia dari: URL: HYPERLINK http://bmcresnotes.biomedcentral. com/articles/10.1186/1756-0500-7-720

16. Pratomo J. Kematian ibu dan kematian perinatal pada kasus rujukan obstetri di RSUP Dr. Kariadi Semarang (tesis). Semarang: Program Pendidikan Dokter Spesialis Obstetri Ginekologi Fakultas Kedokteran Universitas Diponegoro; 2013.
17. Duckit K, Harrington D. Risk factors for preeclampsia at antenatal booking: systematik review of controlled studies. 2005 (diunduh 29 Januari 2016). Tersedia dari: URL: HYPERLINK http://www.ncbi.nlm.nih.gov/pubmed/15743856

18. Eltahir A. Refusing to accept maternal mortality. Boston: Pathfinder International; 2009.

19. Widarta GD, Laksana MAC, Sulistyono A, Purnomo W. Deteksi dini risiko ibu hamil dengan kartu skor Poedji Rochjati dan pencegahan faktor empat terlambat. 2015 (diunduh 6 Maret 2016). Tersedia dari: URL: HYPERLINK http://journal. unair.ac.id/deteksi-dini-risiko-ibu-hamil-dengankartu-skor-poedii-rochjati-dan-pencegahan-faktorempat-terlambat-article-9787-media-57-category3.html

20. Wahyuningsih HP, Rasjad AS, Wirakusumah FF. Hubungan pengetahuan dan sikap bidan tentang rujukan kasus obstetri dengan ketepatan rujukan: suatu studi analisis verifikatif di Kabupaten Bantul, Yogyakarta. 2011 (diunduh 6 Maret 2016.). tersedia dari: URL: HYPERLINK http://indonesia. digitaljournals.org/index.php/lJOG/article/download 1954/953 - 